\title{
Impact of Humor Advertising on Brand Purchase Strategy
}

\author{
Amin Palikhe*
}

\begin{abstract}
The humor advertisement is important for every types of marketer. The main aim of the study is to analyze the impact of humor advertisement on the brand purchasing strategy of consumers. This study used descriptive research design by testing the hypothesis with dependent and independent variables. The questionnaire based survey has been undertaken upon the sample of 136 respondents. Furthermore, data analysis has been carried forward with the help of SPSS through regression and correlation. The results reveal that there is no significant relationship exists between the independent variable (humor advertisement) and the dependent variables (brand attitude, brand memories, purchase intention). There is low correlation between humor advertisement and brand attitude that shows $p<0.1$. Industries have been spending huge amount of money on humor advertisement but the study has also revealed that there is no significant changes in brand purchase strategy of consumer by appealing humor advertising. Test results of correlation and regression shows that humor advertisement can 't make brand purchase strategy. Therefore study of consumer behavior is important to create brand purchase strategy and spending nature of consumer towards advertised products.
\end{abstract}

Keywords: Advertisement, brand, humor, impact, purchase.

\section{INTRODUCTION}

Humor is a growing trend in today's marketing sphere. Humor is the most common and frequently used emotion appeals in advertising (Weinberger \& Spotts, 1989). For any business advancement, the advertisement is an unavoidable tool for the positioning and promotion of the brand and product sale (Beard, 2005). The humorous advertising are analyzed and published in TV as well in print (Madden \& Weinberger, 1984). Advertising is the center for attracting more people and it is become a powerful communication force. Products, services, ideas, images, and many things can easily show advertising and it helps to sell any product or services. Advertisement communicates the impart information and knowledge about the product and services. It leads to the consumers get attention by arousing interest and acceptance of the product. So, humor is more effective in influencing audience attitudes toward both the ad and brand when involvement is relatively low rather than high. The humorous ads always produce better results compared to non-humorous ads.

Over the last century humor theories have been developed and researchers are getting more insight in the basics of humor. However, no final theory has been developed so far and researchers are still trying to figure out what the best way is to explain humor. Although there is no final understanding of humor yet, it has been found that humor is a way to communicate and persuade and therefore a good tool to use in advertisements (Elbers, 2013). Speck found in a research that humorous advertisements outperform non-humorous advertisements on attention (Speck, 1987). According to Eisend (2009), a

*Mr. Palikhe is Lecturer in Faculty of Management, Prithvi Narayan Campus, Tribhuvan University.

Email: a2shrestha@gmail.com 
humorous advertisement can elicit a positive attitude towards the advertisement, elicit a positive attitude towards the brand and it can increase purchase intentions. Needless to say, marketers these days are creating more humorous advertisements to attract the attention of consumers and to, in the end, increase the purchase intention.

One of the main goals of a marketer is to grasp the customers' attention in order to establish strong cognition paths for the advertisement and the brand (Pieters, Warlop, \& Wedel, 2002). Humor in advertisements is therefore not ignored by marketers since research has shown that humor in advertisements increases attention (e.g. Duncan, 1979; Madden \& Weinberger, 1984; Speck, 1987; Sternthal \& Craig, 1973; Weinberger \& Gulas, 1992). Not only in television advertisements, but also on the internet and in magazines, humor is used as a trigger to get attention.

Humor is characterized in terms of the stimulus properties and that humor in advertisements might be determined when the advertisement makes use of pun, joke, understatement and other humor devices (Sternthal \& Craig, 1973). A humor device can be seen as the type or technique of humor that is used to make an advertisement 'humorous'. The seven humor devices of Kelly \& Solomon (1975) are: (a) puns, (b) understatement, (c) jokes, (d) ludicrous, (e) satire, (f) irony, and (g) intent.

Due to globalization, there is a need for cross-cultural approaches and global advertisements (Hatzithomas, Zotos, \& Boutsouki, 2011). The close relation between culture and communication demands that multinational companies should keep in mind that cultural factors are very important in planning a cross-cultural communication strategy. Marketers have to consider the fact that their target group can have a different culture than the one they have at home (Weinberger \&Spotts, 1989). When the culture is different than the one the marketer has in his own country, the target group might have different attitudes; beliefs and motivation towards the product category of the product that the company wants to sell (Novcic \& Damnjanovic, n.d.).

Most of the studies towards global advertisements, humor is most used in different countries while the effectiveness of humorous television advertisements in a global setting has rarely been measured. In Nepalese context, the success of any company relies on the acceptance of humor content of advertisements as humor appeal is liked by large pool of people, can persuade consumers and attract the attention of consumers towards the product and brand. In order to understand the acceptability of humorous advertisements by the Nepalese consumers, research needs to be conducted with regard to their attitudes towards humorous advertising. This is because majority of research were conducted with regard to humor appeal ads in foreign countries and it may not be directly applied to the Nepalese context due to cultural differences and differences in the use of adoption of technology and resources. Therefore, specific research questions were developed to measures impact of humor advertisement impact on brand purchase strategy of consumer. The answer to a research question was help address a "Research Problem" which is a problem that readers think is worth solving. Following are the research questions incurred with this study:

- Do humorous advertisements have an impact on the purchase intention of consumers?

- Is there an impact of humorous advertisements on the brand attitude of consumers?

- Is there effect on brand awareness due to the presence of humorous advertisements?

- Do humorous advertisements actually affect the consumer's brand memory?

Not all studies would have been hypothesized. Sometimes a study is designed to be exploring to hidden behavior. Perhaps the purpose of the study was to explore some specific hypothesis or prediction 
that was tested in the research. Therefore, following hypotheses was associated with this study:

$\mathrm{H}_{1}$ : Humorous advertisements have no positive and significant relationship with Purchase Intention.

$\mathrm{H}_{2}$ : Humorous advertisements have no positive and significant relationship with Brand Attitude.

$\mathrm{H}_{3}$ : Humorous advertisements have no positive and significant relationship with Brand Awareness.

$\mathrm{H}_{4}$ : Humorous advertisements have no positive and significant relationship with Brand Memories.

\section{LITERATURE REVIEW}

\subsection{Concept of Humor Advertising}

A humorous ad can be described shortly as a funny ad. The humor does not have a clear definition as it has many dimensions; Humorous Ads (HA) become successful when the audiences have positive responses for it; it has at least six dimensions that are: "(1) Humor production (2) A sense of playfulness (3) The ability to use humor to achieve social goals (4) Personal recognition of humor (5) Appreciation of humor (6) Use of humor as an adaptive mechanism". Moreover, humor has four items in general: Initiator, the person who is attempting to create the humor; Receiver, the one targeted by the humor; Focus, the thing or the one the humor is about; Publics, those who see or hear the humor (Duncan \& Nelson, 1985).

Humor in advertising is a delicate method of attracting a viewer's/listener's attention to the client's product. Done right, it achieves success. Doing it right means not only engaging the prospect but getting them to remember the product. Many of the most memorable ad campaigns around tend to be funny. Advertisers use this strategy to attract customers to their product. Audiences like to be entertained, people will pay more attention. Humorous content of the message may contain persuasive effect, increase message linking and create positive mood. Humor can occur in various forms, types and have different communication objectives (Speck, 1987).

Humor is a universal phenomenon that is easy to spot and enjoy, often triggering laughter. It is also an elusive entity that is difficult to define and analyze. A dictionary definition of humor is the quality of being amusing or comic, the ability to express humor or amuse other people, a mood or state of mind. Nowadays, humor appeal is being used extensively sometimes combined with others, but most of the time it is strong enough to be used solely. Humor in advertising constitutes billions of dollars in spending each. A variety of benefits have been suggested for humorous appeals. If humor is not recognized or is perceived as not funny it could cause serious negative effects to the advertised product. This is the case when humor is perceived as boring, offensive and reduces credibility. Humor sometimes does not paysoff. The failed humor is viewed as annoying, not useful, not entertaining and not original. These residual effects emphasize the downside risk of using humor in advertisement (Djambaska, 2016).

In this age of increasing competition, advertising has become an essential tool for firms to communicate with the consumers and market their products. Advertising is a means of communication with the users of a product or service. In today's world, advertising uses every possible media to get its message through. It does this via television, print (newspapers, magazines, journals, etc.), radio, press, internet, direct selling, hoardings, mailers, contests, sponsorships, posters, clothes, events, colors, sounds, visuals and even people (K.C.,2016). 


\subsection{Review of Past Studies}

Eisend (2017) pointed that evolutionary psychologists' explanations of the functions of humor can provide new or alternative explanations for these findings and suggest new research avenues. The evolutionary functions of humor have been widely discussed in the literature, but advertising researchers have neglected biological nature and biological evolution as additional or alternative explanations for humor in advertising. The paper contributes to the advertising literature and broadens perspectives for research on humor in advertising by reviewing research on the evolutionary functions of humor, by showing how these functions can explain the use, effects, and moderators of humor in advertising beyond the explanations provided in prior literature, and by suggesting new propositions for future research on humor in advertising.

Mehmood and Masood (2016) has conducted a research study on, "impact of humor in advertising on consumer purchase intention in Ufone network out of telecommunication sector of Pakistan" to find out the impact of humorous advertising and on consumer purchase intention. This was the descriptive study and the probability and convenience sampling techniques was used for the collection of data through questionnaire on five point Likert scale from 200 respondents conveniently from the users of telecommunication sector of Pakistan. Correlation and regression were used as statistical test of data. SPSS was used to analyze the data. The finding of the study were as humor in advertising has significant impact on consumer purchase intention to improve the relations with purchase intention and humor in advertising in Pakistan, humor increase consumer perception about products and humorous nature of advertisement enhanced attention against non- humorous advertisement.

Djambaka, Petrovska and Bundalevska (2016) has conducted a research study on, "Is Humor Advertising Always Effective? Parameters for Effective Use of Humor in Advertising" with the objectives to find out parameters used to produce higher effectiveness of the product advertised and their correlation in appropriate products use of humor in advertisement. The research was mainly base on primary and secondary data. Primary data were collected by questionnaire method from two groups (young high educated and social network people). The major finding of the study was that people find humorous message more effective than serious version of the message, humor attracts attention, may increase liking for the source and create a positive mood, humor makes the advertisement more memorable and leaves long term positive feeling inside the consumer after seeing them, humor has word-of -mouth effect and easily became "talk" in town and $60 \%$ of the time humor cost-effective.

Hoang (2013) has conducted a research study on, "Impact of humor in advertising on consumer's purchase decision". The objectives of the study were to study the consumer decision process and its determinants, to explore the concept and usage of humor in advertising and to find out humor advertisement impact on consumer purchase decision. The theoretical framework gathered data from article, books and previous research. The research had an aim to find out Vietnamese consumer buying decision. The primary data were collected from transcripts of interviews and recorded observation. The researcher used quantitative and qualitative research methods. The findings showed that humorous advertising had an impact on consumer's recall and tend to undertake nominal and limited decision making. Humor has relatively impact on encouraging repurchase but appropriate for building brand's image and gain consumer's fondness and the consumers of "yellow goods" are variety seeking buyers.

Chung and Zhao(2003) examined the moderating effects of product involvement on the effects of humor on memory and attitude towards the advertisement by using multi-year survey (1992 to 1997) of responses to commercials shown during the Super Bowl. Positive and significant relationships between 
humorous advertisements on memory and attitude were found through multiple regression analysis. Furthermore, results show that humorous advertisements are more effective in low-involvement products in terms of memory and attitude towards the advertisement.

\section{Conceptual Framework}

Independent Variables $\quad$ Dependent Variable

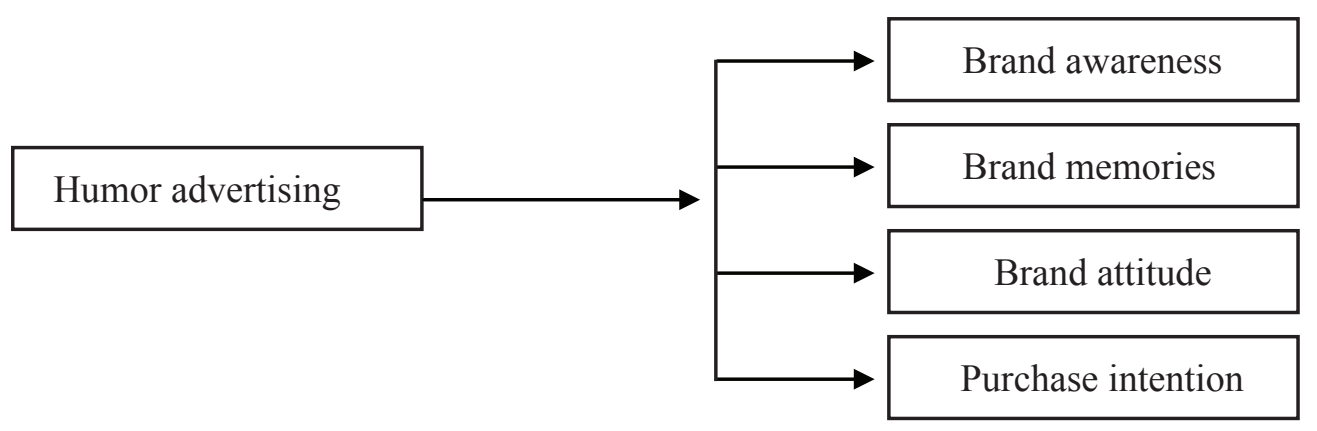

Figure 1. A model of an impact of humor advertisement brand purchase strategy.

From above studies, following conceptual framework has been developed for the measuring an impact of humor adverting for consumer brand purchase strategy.

\section{Independent Variable}

The independent variable is the variable which determines the value of the dependent variable, i.e. there are various factors that influence the consumer brand perception. Out of many such factors, the one chosen for this study is humorous advertisements. Humorous advertisement is the single independent variable which has relationship with other dependent variables.

\section{Dependent Variables}

Dependent variable is the variable that is being measured in the experiment. It is the variable whose value depends upon other factors. The study aims to measure and evaluate the impact of humor advertising (independent variable) on consumer brand perception. Here, the brand perception of consumers is determined by the dependent variables such as brand attitude, purchase intention, brand awareness and brand memories.

\section{Purchase Intention:}

The willingness of a customer to buy a certain product or a certain service is known as purchase intention. It is a dependent variable that depends on several external and internal factors. It is frequently measured and used by marketing managers as an input or decisions about new and existing products and services. It is correlated and predict future sales, but do so imperfectly.

\section{Brand Awareness:}

Brand awareness is an approach for measuring the strength of the impression made in consumers' minds. It exercises great impact on consumers' decisions, suggesting that brand awareness was often the foremost consideration in decision-making. Here, the relation between brand awareness as a dependent 
variable and humorous advertisement is drawn out.

\section{Brand Attitude:}

Brand attitude is a dependent variable in this study which is defined as an attitude that in terms of any brand is a lasting and is generally evaluated by people. It consists of three parts: affect, behavior and cognition. Affect refers to the way a consumer feels about an attitude object. Behavior involves the person's aims to do something related to an attitude object. Cognition refers to a consumer's belief holding towards an attitude object. So as a whole brand attitude is studied in relation to humor advertising

\section{Brand Memories:}

Brand recognition is how we access information in our memory to identify a brand. Brand memories can be divided into two main categories, namely unaided and aided memories. A brand's value is directly connected to its presence in the memory of consumers. It is a dependent variable in this study and its relationship in terms of humorous advertisements is studied.

\section{DATA AND METHODS}

This survey was based upon the primary data. This survey used descriptive cum analytical research design to interpret the research finding. The data was collected by formulating a set of questionnaire and the questionnaire was distributed to the respondents. The questionnaire contained close-ended questions. Most of the close-ended questions were measured using six rating Likert scale to create and easy to answer an unbiased questionnaire. Population for the study is defined in term of people from different phase of life, who are used to viewing advertisements in Pokhara. In this study, convenience sampling was used because sample was made up of people who are easy to reach. The age of respondents started as under 20 and above 50. Elaborating the age group, the questionnaire was distributed to 5 different categories of age group i.e. below 20, 21-30, 31-40, 41-50 and 51 and above. The main reason for making a wider gap in the age group was to collect the views of different people as different products are targeted to different age groups. The questionnaire was distributed to different categories of age group, education level, gender and religion under this study. The researcher distributed questionnaires to a total of 136 respondents. The study is based on various statistical tests such as correlation, regression including mean and standard deviation and it was calculated by using the software called Statistical Package for Social Science (SPSS) to analyze and interpret the quantitative data. A significant level of 5\% and 10\% and one tail test had been used under this study. Validity was measured through development of construct of the concept and thoroughly consults with expert researchers and Cronbh's Alfa was used to make reliability of the data. Ethical standard was maintain by respecting each respondents' attitude and behavior.

\section{RESULTS AND DISCUSSION}

This section is sub-divided into the first part respondents' profile second part analyses and interprets the collected data through analysis and interprets the correlation between dependent and independent variables including discussion and results obtains through analysis. 
Table 1

Respondents 'Profile of Study Group

\begin{tabular}{lr}
\hline Characteristics & Frequency \\
\hline Gender & $59(43.4)$ \\
\hline Female & $77(56.6)$ \\
Male & $14(10.3)$ \\
\hline Age & $100(73.5)$ \\
\hline Below 20 & $7(5.1)$ \\
$21-30$ & $4(2.9)$ \\
$31-40$ & $11(8.1)$ \\
$41-50$ & $5(3.7)$ \\
51 and above & $3(9.6)$ \\
\hline Education & $32(38.2)$ \\
\hline SLC & $66(48.5)$ \\
Intermediate & \\
Bachelor & $75(55.15)$ \\
Master & $22(16.18)$ \\
\hline Religion & $4(2.94)$ \\
\hline Hinduism & $33(24.26)$ \\
Ishristianity & $2(1.47)$ \\
\hline Buddhism &
\end{tabular}

Source: Field survey, 2018.

Note: Parenthesis indicates the percentage of total responses.

Table 1 shows the gender, age, education and religion mix of respondents. Male respondents are taken more than female respondent for the study. Maximum $(73.5 \%)$ percentage respondents are fall under the age group of 21-30 of age. Whereas $48.5 \%$ of respondents are from master degree and $55.15 \%$ are taken Hindu for the study.

Table 2

Mean, Standard Deviation, and Inter-Correlations of Study Variables

\begin{tabular}{|c|c|c|c|c|c|c|c|}
\hline Variables & Mean & Std. deviation & 1 & 2 & 3 & 4 & 5 \\
\hline 1.Humor advertisement & 4.7559 & .47497 & & .034 & -.069 & .010 & $.115^{* *}$ \\
\hline 2. Purchase intention & 3.7897 & .50498 & & & .054 & .076 & -.050 \\
\hline 3. Brand attitude & 4.1820 & .54388 & & & & $.165^{*}$ & -.064 \\
\hline 4. Brand memories & 4.6716 & 69919 & & & & & .008 \\
\hline 5. Brand awareness & 4.6673 & .58930 & & & & & \\
\hline
\end{tabular}

Source: Field survey, 2018.

Note. $\left.{ }^{*} \mathrm{p}<0.05, * * \mathrm{p}<0.1\right)$. 
Table 2 presents the mean, standard deviation and inter-correlation of study variables. First, it indicates that humor advertisement has highest mean $(\mathrm{M}=4.7559)$ than other variables. The result shows that humor advertisement has great impact on the brand purchase strategy of the companies. They agreed on that and it was low standard deviation (SD) with compare to other variables. Likewise, there is significant relationship between the humor advertisement and brand awareness and brand attitude and brand memories has also significant relationship. Humor advertisement had positive and low degree of correlation with purchase intention, brand memories and brand awareness but negative correlation with brand attitude.

Table 3

Mean, Standard Deviation, and Correlations of Study Variables (Dependent and Independent)

\begin{tabular}{lrrr}
\hline Variables & Mean & Std. Deviation & Correlation \\
\hline Independent variables(Humor advertisement) & 4.7559 & .47497 & 0.044 \\
Dependent variables(overall ) & 4.3276 & .30939 & \\
\hline
\end{tabular}

Source: Field survey, 2018

Table 3 reveals that there is low degree of correlation with the dependent variables: brand awareness, brand attitude, brand memories and purchase intention as well there is no significant relationship between dependent and independent variables.

To test the hypothesis, the multiple regression analysis was conducted to analyze the variability of each dependent variable: brand awareness, brand memories, brand attitude and purchase intentions, of the impact on the use of humor advertisement are regressed. The study assumed that there is a linear relationship between the humor advertisement and study variables: brand awareness, brand memories, brand attitude and purchase intention. The multiple regression analysis is the method of assessing the strength relationship independent variable to dependent variables where independent variable humor advertisement is a predictor of creating brand awareness, brand memories, brand attitude and purchase intention. The analysis was used to determine how well the humor advertisement impacted on the brand awareness, brand memories, brand attitude and purchase intention.

Table 4

Multiple Regression Analysis Predicting for Brand Awareness, Brand Memories, Brand Attitude and Purchase Intention

\begin{tabular}{lrrr}
\hline Variables & $\begin{array}{c}\text { Beta } \\
\text { coefficient }\end{array}$ & t-value & p-value \\
\hline Purchase intention & 0.034 & 0.001 & 0.154 \\
Brand attitude & -0.069 & 0.005 & 0.642 \\
Brand memories & 0.010 & 0000 & 0.012 \\
Brand awareness & 0.115 & 0.013 & 1.803 \\
Dependent variables & 0.044 & & \\
\hline R2 & 0.002 & & \\
\hline F & 0.257 & & \\
\hline
\end{tabular}

Source: Field survey, 2018.

Note. values in tables are standardized beta coefficient. 
Table 4 reveals that humor advertisement explained a significant amount of the variance in the brand attitude, brand awareness, brand memories and purchase intention. With respect to the study, humor advertisement was not significant predictors of creating such images for customer where some of the images that humor advertisement can create negative image towards brand attitude.

Table 5

Model Summary- Humor Advertisement and Impact on Dependent Variables

\begin{tabular}{lrrrr}
\hline Model & $\mathrm{R}$ & R square & Adjusted R square & Std. error of the estimate \\
\hline 1 & .044 & .002 & -.006 & .31025 \\
\hline
\end{tabular}

a. Predictors: (Constant), HADV (humor advertisement)

Source: Field Survey, 2018

The summary model table 5 shows the coefficient determination (R2) was 0.002 . This meant that humor advertisement has just 2 percent of impact on the variation of dependent variables: brand awareness, brand memories, brand attitude and purchase intention.

Table 6

ANOVA-Humor Advertisement and Overall Study Variable

\begin{tabular}{rlrrrrr}
\hline Model & & Sum of squares & df & Mean square & F & Sig. \\
\hline \multirow{2}{*}{1} & Regression & .025 & 1 & .025 & .257 & $.613^{\text {b }}$ \\
& Residual & 12.898 & 134 & .096 & & \\
& Total & 12.923 & 135 & & & \\
\hline
\end{tabular}

a. Dependent Variable: DV (brand awareness, brand attitude, brand memories, purchase intention)

b. Predictors: (Constant), HADV (humor advertisement)

Source: Field survey, 2018

From the ANOVA table regression SS is 0.025 , and total regression is 12.9 which means regression explain that $0.0000206 \%(0.025 / 12.9)$ of all the variability in the given data set. Residual SS is 12.89 . In general, small error of sum of square is better and it explains better regressional relationship between independent variable and dependent variables. The analysis revealed that the F-value is 0.257 and $\mathrm{p}=.63$. The model therefore not significant because $\mathrm{p}>0.05$. it was concluded that humor advertisement has no significant impact on brand awareness, brand attitude, brand memories and purchase intention.

Table 7

Multiple Regression Analysis Results- Humor Advertisement and Overall Dependent Study Variable

\begin{tabular}{|c|c|c|c|c|c|c|}
\hline \multirow[t]{2}{*}{ Model } & & \multicolumn{2}{|c|}{$\begin{array}{l}\text { Unstandardized } \\
\text { coefficients }\end{array}$} & \multirow{2}{*}{$\begin{array}{c}\text { Standardized } \\
\text { coefficients } \\
\text { beta }\end{array}$} & \multirow[t]{2}{*}{$\mathrm{t}$} & \multirow[t]{2}{*}{ Sig. } \\
\hline & & $\mathrm{B}$ & Std. error & & & \\
\hline & (Constant) & 4.192 & .269 & & 15.602 & .000 \\
\hline 1 & $\begin{array}{l}\text { HADV } \\
\text { (humor advertisement) }\end{array}$ & .029 & .056 & .044 & .507 & .613 \\
\hline
\end{tabular}

a. Dependent Variable: DV (brand awareness, brand attitude, brand memories, purchase intention)

Source: Field Survey, 2018 
Analysis of the regression model results revealed that humor advertisement $(\beta=.044, \mathrm{p}=0.61)$ was not directly and significantly related to creating brand awareness, brand attitude, brand memories or purchase intention. The finding implies that customer was not convinced with humor advertisement that creates such images for customers.

\section{CONCLUSION}

Humorous advertisement is one of the popular types of advertising for consumer and industrial product and is increasingly being used by industries for branding to impress and attract their customers in the market. Different media is being used to create brand decision of consumer so that it can be assumed that humor advertisement can enhance customer credibility and create brand awareness, brand attitude, brand memories and purchase intention. The analyses and evaluation above have been able to prove that there is an unfortunate impact of humor advertising on the consumer purchasing decisions. The study was able to identify that the purchasing decision of the consumer's is largely dependent upon their willingness to purchase particular products on exactly humor advertisement that have been done by industries. The correlation analysis explored that there is either positive or negative direction of the dependent and independent variables, while the regression analysis has estimated the impact of independent variable on the dependent variable and the sig. the value obtained from the regression analysis has helped in testing the hypothesis of the research. The results also reveal that significant relationship exists between the humor advertisement and brand awareness $(\mathrm{R}=0.115)$ but all the dependent variables as the value of significance have not appeared to be less than p-value 0.05 with independent variable humor advertisement. Therefore the regression analysis reveals that there is little bit chance of variation through appealing of humor advertisement for various product of consumers' brand purchase strategy.

\section{REFERENCES}

Beard, F. K. (2005). One hundred years of humor in American advertisement. Journal of Macro Marketing, 25(1), 54-65. doi: 10.1177/0276146705274 965

Chung, H., \& Zhao, X. (2003). Humor effect on memory and attitude: moderating role of product involvement. International Journal of Advertising, 22(1), 117-144. doi:10.1080/02650487.2003.1107284

Djambaska, A., Petrovska, I., \& Bundalevska, E. (2016). Is humor advertising always effective? Parameters for effective use of humor in advertising. Journal of Management Research, 8(1), 1-19.

Duncan, C. P., \& Nelson, J. E. (1985). Effects of humor in a radio advertising experiment. Journal of Advertising, 14( 2), 33-40.

Eisend, M. (2009). A meta-analysis of humor in advertising. Journal of the Academic Marketing Science, 39, 191 $-203$.

Eisend, M. (2017).Explaining the use and effects of humor in advertising: an evolutionary perspective. International Journal of Advertising, 37(4), 526-547. doi:10.1080/02650487.2017.1335074

Elbers, J. S. (2013). Humorous advertisements and their effectiveness among customers with different motivational values (Master's thesis, University of Twente).

Hatzithomas, L., Zotos, Y., \& Boutsouki, C. (2011). Humor and cultural values in print advertising: a cross-cultural study. International Marketing Review.

Hoang, A. T. (2013). Impact of humor in advertising on consumer purchase decision. Lappeenranta: Saimaa University of Applied Sciences.

K.C., D. (2016). Advertising in the changing world. Retrieved from http://www.adnepal.org.np/viewcontent. 
php?mainid=299\&content_id=276

Kelly, J. P., \& Solomon, P. J. (1975). Humor in television advertising. Journal of Advertising, 4(3), 31-35.

Madden, T. J., \& Weinberger, M. G. (1984). Humor in advertising: A practitioner view. Journal of Advertising Research, 24, $23-29$.

Mehmood, H. A. M. I. D., \& Masood, S. A. A. D. (2016). Impact of humor in advertising on consumer purchase intention: A Study on Ufone network from telecommunication sector in Pakistan. International Review of Management and Business Research, 5(3), 1232-1240.

Novcic, B., \& Damnjanovic, V. (n.d.). Cross cultural differences in TV advertising, comparative study: USA, Austria and Serbia.

Oxford University Press. (2016). Humor. Retrieved from https://en.oxforddictionaries.com/ definition/humour

Pieters, R., Warlop, L., \& Wedel, M. (2002). Breaking through the clutter: Benefits of advertisement originality and familiarity for brand attention and memory. Management Science, 48 (6), 765 - 781.

Speck, P. S. (1987). On humor and humor in advertising (Doctoral dissertation, Texas Tech University).

Sternthal, B., \& Craig, C. S. (1973). Humor in advertising. Journal of Marketing, 37, 12 - 18.

Weinberger, M. G., \& Gulas, C. S. (1992). The impact of humor in advertising: A review. Journal of Advertising, $21(4), 35-59$.

Weinberger, M. G., \&Spotts. H. E. (1989). Humor in US versus UK TV commercials: A comparison. Journal of Advertising, 18 (2), 39 - 44. 